\title{
The Effect of Feeding Dried Distillers Grains Plus Solubles on Milk Production and Excretion of Urinary Purine Derivatives ${ }^{1}$
}

\author{
B. N. Janicek, ${ }^{*}$ P. J. Kononoff, ${ }^{* 2}$ A. M. Gehman, ${ }^{*}$ and P. H. Doane \\ *Department of Animal Science, University of Nebraska, Lincoln 68583-0908 \\ †ADM Research, Decatur, IN 46733
}

\begin{abstract}
Two studies were performed to evaluate the effects of dried distillers grains with solubles (DDGS) on the lactational performance of dairy cows. The intent of experiment 1 was to evaluate the effects of feeding increasing concentrations of DDGS on the feed intake and production of Holstein dairy cows. Twenty multiparous Holstein cows averaging $76 \pm 24 \mathrm{~d}$ in milk and $638 \pm 68$ $\mathrm{kg}$ of body weight were randomly assigned to one of five $4 \times 4$ Latin squares. During each of the 28-d periods, cows were offered 1 of 4 diets: 1) control, 0\% DDGS, 2) $10 \%$ DDGS, 3) $20 \%$ DDGS, or 4) $30 \%$ DDGS. For the treatment diets, DDGS replaced a portion of both forages and concentrates. Dry matter intake increased linearly with increasing concentrations of DDGS (21.4, $22.4,23.0$, and $24.0 \pm 0.98 \mathrm{~kg} / \mathrm{d}$ ). Similarly, milk production increased linearly $(27.4,28.5,29.3$, and $30.6 \pm 1.44$ $\mathrm{kg} / \mathrm{d})$. The intent of experiment 2 was to evaluate the effect of feeding DDGS on feed intake, milk production, and excretion of urinary purine derivatives (PD). Excretion of PD was used to estimate the effects on rumen microbial crude protein production. Twenty-one multiparous and 13 primiparous Holstein cows, averaging $178 \pm 36 \mathrm{~d}$ in milk and $651 \pm 65 \mathrm{~kg}$ of body weight were randomly assigned to 1 of 2 diets in a 3-period crossover design. Cows were offered 1 of 2 rations during each 21-d period. Dietary treatments were either a control (0\% DDGS) or $30 \%$ dietary dry matter of DDGS. Dry matter intake increased when feeding DDGS (22.8 vs. $24.1 \pm 0.74 \mathrm{~kg} / \mathrm{d}$ for 0 and $30 \%$ DDGS, respectively) but milk production, percentages of milk fat and protein, and the ratio of PD to creatinine were not significantly different between the control and DDGS diets. Results of this study suggest a dairy ration may be formulated
\end{abstract}

\footnotetext{
Received October 14, 2007.

Accepted April 28, 2008.

${ }^{1} \mathrm{~A}$ contribution of the University of Nebraska Agricultural Research Division, supported by funds provided through the Hatch Act. Mention of a trade name, proprietary products, or company name is for presentation clarity and does not imply endorsement by the authors of the University of Nebraska.

${ }^{2}$ Corresponding author: pkononoff2@unl.edu
}

to contain as much as $30 \%$ of dietary dry matter as DDGS.

Key words: dairy cow, distillers grains, lactational performance, urinary purine derivative

\section{INTRODUCTION}

Recent growth of the US ethanol industry has increased the supply of feed co-products, most commonly dried distillers grains plus solubles (DDGS). Dried distillers grains are low in lignin (4.3\%) and contain approximately $38 \% \mathrm{NDF}$ (NRC, 2001). This NDF is highly digestible (67.8\%; Getachew et al., 2004) and may supply energy without increasing the ruminal acid load in the manner characteristic of high-starch concentrates (Ham et al., 1994). Typically, dairy nutritionists limit inclusion of DDGS to $10 \%$ of the dietary DM because of its high fat content, which typically ranges between 10 and $12 \%$. Dietary fat can negatively affect fiber digestion (Van Soest, 1994) and may also contribute to milk fat depression (Pantoja et al., 1994). Considering recent changes in the grain markets and continued expansion of ethanol production, the feasibility of feeding diets composed of greater than 10\% DDGS is of interest.

As dry corn milling ethanol production grows and evolves, the nature of co-products varies and also continues to change. For example, one process currently used is to partially remove the germ before fermentation. Because this component of the corn kernel is high in both $\mathrm{P}$ and fat (Ponnampalam et al., 2004), the expected product is believed to be lower in these nutrients. However, given that some fat remains even after germ removal and that the proportion of solubles added back to the coarse grains may vary, DDGS produced from this process still contains fat. Studies that examine ration formulation approaches that seek to include this feed at varying levels should provide continued insight into the impact on feed intake and milk production.

In this study, 2 experiments were carried out to evaluate the effects of feeding increased concentrations of DDGS. The DDGS used in this experiment originated from a dry-milling plant, which partially removes the germ before fermentation. The objectives 
of these experiments were 1) to evaluate the effects of feeding increasing concentrations of DDGS with the aim of identifying a maximum point of inclusion in dairy rations and 2) to evaluate the effects of feeding a high proportion of DDGS on rumen microbial protein (MCP) production based on excretion of urinary purine derivatives (PD).

\section{MATERIALS AND METHODS}

\section{Experimental Treatments and Design}

Two experiments were conducted in which Holstein cows were housed in individual stalls and milked at 0730 and $1930 \mathrm{~h}$. Cows were fed at $1000 \mathrm{~h}$ for ad libitum consumption to allow for approximately $5 \%$ refusals. The experimental cows were cared for according to the guidelines stipulated by the University of Nebraska Animal Care and Use Committee (IACUC no. 05-11070D). Experiments were conducted at different times and used different ingredients.

\section{Experiment 1}

Twenty multiparous Holstein cows (BW $638 \pm 68 \mathrm{~kg}$; DIM $76 \pm 24$ ) were used to study the effect of feeding increasing concentrations of DDGS on milk production and composition. Cows were randomly assigned to one of five $4 \times 4$ Latin squares. During each of the 28-d periods, cows were offered 1 of 4 dietary treatments. Treatments differed by the proportion of DDGS replacing both forage and concentrate ingredients. Dietary treatments were as follows: 1) control, 0\% DDGS; 2) 10\% DDGS; 3) 20\% DDGS; and 4) 30\% DDGS. Treatments 2 and 3 were a mixture of the control and $30 \%$ DDGS treatments. Treatments 2 and 3 were achieved by varying proportions of the control and 30\% DDGS treatments, which were delivered to the feed bunk and mixed by hand with a pitchfork. Table 1 lists the ingredient composition for the 0 and 30\% DDGS treatments and Table 2 lists the chemical composition of these treatments. Diets were formulated to be similar in $\mathrm{CP}, \mathrm{NDF}$, and energy. Table 3 lists the particle size of the TMR fed in experiment 1. According to the NRC (2001) and assuming a DMI of $21.9 \mathrm{~kg} / \mathrm{d}$, diets were formulated for ME-allowable milk production of 40.1 $\mathrm{kg} / \mathrm{d}$ and MP-allowable milk production of $38.5 \mathrm{~kg} / \mathrm{d}$ for the $30 \%$ DDGS diet, compared with $41.5 \mathrm{~kg} / \mathrm{d}$ for ME-allowable milk production and $39.8 \mathrm{~kg} / \mathrm{d}$ for MPallowable milk production for the control diet.

\section{Experiment 2}

Twenty-one multiparous and 13 primiparous mid- to late-lactation Holstein cows averaging $178 \pm 36$ DIM
Table 1. Ingredient composition of the diets fed in experiment 1

\begin{tabular}{|c|c|c|}
\hline \multirow[b]{2}{*}{ Diet ingredient, \% of DM } & \multicolumn{2}{|c|}{ Diet $^{1}$} \\
\hline & Control & DDGS $^{2}$ \\
\hline Corn silage & 30.1 & 23.9 \\
\hline Alfalfa hay & 10.9 & 9.4 \\
\hline Alfalfa haylage & 10.9 & 9.3 \\
\hline DDGS & - & 30.1 \\
\hline Ground corn & 16.3 & 12.1 \\
\hline Ground soybean hulls & 10.4 & 10.4 \\
\hline Cottonseed & 6.61 & - \\
\hline SoyPass $^{3}$ & 5.60 & 1.14 \\
\hline Soybean meal & 4.77 & - \\
\hline Ground limestone & 0.73 & 0.98 \\
\hline Tallow & 1.04 & 0.92 \\
\hline Bloodmeal & 0.68 & 0.68 \\
\hline Sodium bicarbonate & 0.52 & 0.52 \\
\hline Magnesium oxide & 0.17 & 0.17 \\
\hline Salt & 0.52 & 0.10 \\
\hline Calcium diphosphate & 0.41 & - \\
\hline Urea & 0.26 & - \\
\hline Vitamin ADE premix ${ }^{4}$ & 0.12 & 0.12 \\
\hline Smartamine $\mathrm{M}^{5}$ & 0.04 & 0.04 \\
\hline Trace mineral $^{6}$ & 0.04 & 0.04 \\
\hline Vitamin E premix & 0.03 & 0.03 \\
\hline Sel-Plex $1000^{7}$ & 0.02 & 0.01 \\
\hline
\end{tabular}

${ }^{1}$ Control $=0 \%$ dried distillers grains plus solubles; DDGS $=30 \%$ dried distillers grains plus solubles (DM basis).

${ }^{2} \mathrm{DDGS}=$ dried distillers grains plus solubles.

${ }^{3}$ LignoTech (Overland Park, KS).

${ }^{4}$ Formulated to supply approximately 120,000 IU/d of vitamin A, $24,000 \mathrm{IU} / \mathrm{d}$ of vitamin $\mathrm{D}$, and $800 \mathrm{IU} / \mathrm{d}$ of vitamin $\mathrm{E}$ in the total ration.

${ }^{5}$ Approximately $75 \%$ CP (Adisseo, Alpharetta, GA).

${ }^{6}$ Formulated to contain $1.0 \% \mathrm{Ca}, 0.50 \% \mathrm{P}, 0.36 \% \mathrm{Mg}$, and $1.3 \% \mathrm{~K}$.

${ }^{7}$ Alltech Inc. (Nicholasville, KY).

and weighing $651 \pm 65 \mathrm{~kg}$ were used to evaluate the effect of feeding a high concentration of DDGS on milk production and urinary PD excretion to estimate rumen MCP production. Cows were randomly assigned to 1 of 2 diets that differed by the rate of inclusion of DDGS and that were fed in a 3-period crossover design with 21-d periods. Cows were randomly assigned to 1 of 2 sequences (ABA and $\mathrm{BAB}$ ), and the number of treatments used in each period was balanced. Diets were chemically similar but differed by the rate of inclusion of DDGS. Dietary treatments were either the control (no DDGS) or $30 \%$ dietary DM DDGS. As in experiment 1, DDGS replaced a portion of both forages and concentrates. Diets were formulated to contain similar concentrations of CP, NDF, and energy. Table 4 lists the ingredient composition, and Table 5 lists the chemical composition of the diets fed in experiment 2 .

\section{Experimental Measures}

Experiment 1. During each of the four 28-d periods, d 1 to 26 were used as an adjustment period and d 27 
Table 2. Chemical composition of diets fed in experiment 1

\begin{tabular}{lcc}
\hline & \multicolumn{2}{c}{ Diet $^{1}$} \\
\cline { 2 - 3 } Chemical, \% of DM & Control & DDGS \\
\hline DM, \% & 53.3 & 52.9 \\
CP & 19.4 & 18.1 \\
RUP, ${ }^{2} \%$ of CP & 35.5 & 41.4 \\
RDP, \% of CP & 64.5 & 58.6 \\
Starch & 22.4 & 21.0 \\
NDF & 34.6 & 37.1 \\
ADF & 23.0 & 22.6 \\
Lignin & 3.94 & 3.10 \\
NE ${ }_{L}^{2}$ Mcal/kg & 1.50 & 1.51 \\
Ether extract & 5.14 & 5.68 \\
NFC & 37.2 & 37.9 \\
Ash & 7.22 & 7.71 \\
Ca & 0.93 & 0.83 \\
Mg & 0.37 & 0.48 \\
P & 0.37 & 0.23 \\
K & 1.46 & 1.28 \\
S & 0.24 & 0.38 \\
\hline
\end{tabular}

${ }^{1}$ Control $=0 \%$ dried distillers grains plus solubles (DDGS) DDGS = $30 \%$ dried distillers grains plus solubles (DM basis).

${ }^{2}$ According to the NRC (2001).

${ }^{3}$ Calculated by the difference $100-(\% \mathrm{NDF}+\% \mathrm{CP}+\% \mathrm{Fat}+\% \mathrm{Ash})$.

to 28 were used for experimental measures. Samples of TMR, forages, and DDGS were collected on d 27 and 28 of each period and subsamples were analyzed for DM, $\mathrm{CP}$, soluble protein, $\mathrm{ADF}, \mathrm{NDF}$, starch, ether extract (EE), and minerals (P, K, Ca, Mg, S, Zn, Cu, Mn, Fe, and $\mathrm{Na}$; Table 6) by Dairy One Laboratory (Ithaca, NY). Neutral detergent fiber was analyzed by using the Ankom A200 filter bag technique, with $4 \mathrm{~mL}$ of a-amylase and $20 \mathrm{~g}$ of sodium sulfite. Starch was determined by using a YSI 2700 Select biochemistry analyzer (Application Note 322, YSI Inc., Yellow Springs, OH). Crude protein was analyzed by the Kjeldahl method, and minerals were analyzed by using a Thermo Jarrell Ash IRIS inductively coupled plasma radial spectrometer (Thermo Jarrell Ash, Franklin, MA), whereas sulfur was analyzed by using the Leco Model SC-432 (Leco, St. Joseph, MI) as described by AOAC (2000). Total mixed ration samples were collected on $\mathrm{d} 27$ and 28 for particle size analysis by using the Penn State Forage Particle Separator as described by Heinrichs and Kononoff (2002). Intakes and refusals were record- ed daily to determine DMI. Body weight and BCS (1 to 5 scale) were measured on $\mathrm{d} 27$ and 28 of each period. Body condition score was measured each time by the same individual and was reported to the quarter point as described by Wildman et al. (1982). Milk production was recorded daily and milk samples were collected on d 27 and 28 during 4 consecutive milkings. One sample from each milking was preserved in 2-bromo-2-nitropane-1,3-diol and analyzed by Heart of America DHIA (Manhattan, KS) for fat and true protein (AOAC, 2000) with a B2000 infrared analyzer (Bentley Instruments, Chaska, MN). An additional sample from each milking was retained without preservative and immediately frozen for fatty acid analysis. For fatty acid analysis, milk samples were methylated (Kramer et al., 1997) and analyzed by gas chromatography (model 5890 Series II gas chromatograph; Hewlett-Packard Corp., Palo Alto, CA). Fatty acid methyl esters were separated on a $30 \mathrm{~m} \times 0.25 \mathrm{~mm} \times 0.2 \mu \mathrm{m}$ film thickness P-2380 fused-silica capillary column (Supelco Inc., Bellefonte, PA). Helium was the carrier gas, and flow rate was 20 $\mathrm{cm} / \mathrm{s}$. A flame-ionization detector and a model 7673 autoinjector were used. The injector temperature was $250^{\circ} \mathrm{C}$, and the detector temperature was $260^{\circ} \mathrm{C}$. The initial column temperature was $50^{\circ} \mathrm{C}$ for $2 \mathrm{~min}$, then increased to $250^{\circ} \mathrm{C}$ at a rate of $4.5^{\circ} \mathrm{C} / \mathrm{min}$ and held at $250^{\circ} \mathrm{C}$ for $15 \mathrm{~min}$. No internal standard was used.

Rumen undegradable CP, digestible RUP (dRUP), and total tract (TT) CP digestibility were determined for bloodmeal and DDGS by using the mobile bag technique described by Kononoff et al. (2007). Approximately $2 \mathrm{~g}$ of freeze-dried and $1-\mathrm{mm}$ ground samples of DDGS and bloodmeal were weighed and placed into 8 (4 per sample) $3.5 \times 5 \mathrm{~cm}$ Dacron bags (Ankom Inc., Fairport, NY) with a pore size of $50 \mu \mathrm{m}$ and then heat sealed (Vanzant et al., 1998). Dacron bags were then placed in mesh bags (50 Dacron bags/mesh bag) and placed in the ventral sac of the rumen of 2 ruminally and duodenally fistulated Holstein steers. Following 16 $\mathrm{h}$ of rumen incubation, one-half of the bags were frozen and used to estimate rumen CP digestion analysis, and the remaining bags (mobile bags) were incubated in a pepsin and $\mathrm{HCl}$ solution $(1 \mathrm{~g}$ of pepsin/L and $0.01 \mathrm{~N}$ $\mathrm{HCl})$ at $37^{\circ} \mathrm{C}$ for $3 \mathrm{~h}$ to simulate abomasal digestion.

Table 3. Particle size analysis (as-fed basis) of experiment 1 diets when using the Penn State Forage Particle Size Separator as described by Heinrichs and Kononoff (2002)

\begin{tabular}{lcccc}
\hline Sieve size & Control TMR & SD & 30\% DDGS ${ }^{1}$ TMR & SD \\
\hline $19 \mathrm{~mm}$ & 8.16 & 1.09 & 4.50 & 1.12 \\
$8 \mathrm{~mm}$ & 37.0 & 2.02 & 26.6 & 9.65 \\
$1.18 \mathrm{~mm}$ & 37.9 & 1.59 & 46.6 & 0.98 \\
Pan & 16.9 & 1.78 & 21.7 & 4.02 \\
\hline
\end{tabular}

${ }^{1} \mathrm{DDGS}=$ dried distillers grains plus solubles. 
After the pepsin-HCl incubation, mobile bags were inserted into the duodenum of each steer each day. The mobile bags were collected in the feces the following day and frozen until all the bags were collected. Bags were machine washed using 1-min washes and 2-min spin cycles repeated 5 times. Residues were analyzed for $\mathrm{N}$ by using the combustion method (AOAC, 2000) in a combustion analyzer (Leco FP-528, Leco, St. Joseph, MI). Digestible RUP (\% of DM) was calculated as the percentage of CP escaping ruminal disappearance but not contained in the residue after intestinal passage. Table 7 presents the results for RUP, dRUP, and TT CP digestibility for the DDGS and bloodmeal.

Experiment 2. During each of the three 21-d periods, $d 1$ to 16 were used as an adjustment period and d 17 to 21 were used for experimental measures. Feed intakes and refusals were recorded daily and cows were weighed and condition scored ( 1 to 5 scale) on d 20 and 21 of each period. Milk production was recorded daily and milk samples were taken on d 19 to 21 during 6 consecutive milkings. Milk composition and feed samples were analyzed as described in experiment 1 . Samples of TMR, forages, and DDGS were collected on d 20 and 21 of each period and subsamples were analyzed as described in experiment 1 (Table 8). On d 18 to 21 , spot urine samples were taken at 0600 and $1800 \mathrm{~h}$. Samples of urine were acidified to $\mathrm{pH}<4$ by using $4 \mathrm{M} \mathrm{HCl}$ and frozen $\left(-20^{\circ} \mathrm{C}\right)$, and this solution was later thawed and composited for each cow during each period and diluted with 39 parts diluent to 1 part urine. Diluent was $0.202 \%$ sodium 1 -heptane sulfonic acid and $0.086 \%$ ammonium dihydrogen phosphate $\left(\mathrm{NH}_{4} \mathrm{H}_{2} \mathrm{PO}_{4}\right)$, and the solution was brought to $\mathrm{pH} 2.1$ with $4 \mathrm{M} \mathrm{HCl}$. Urinary creatinine has been validated as a marker to estimate urine volume (Valadares et al., 1999; Leonardi et al., 2003). The ratio of urinary PD to creatinine is widely used to estimate the MCP flow to the duodenum (Gonda, 1995; Shingfield and Offer, 1998). Both PD and creatinine were analyzed by using an HPLC instrument (Waters Corp., Milford, MA) according to the procedures of Shingfield and Offer (1999). Urinary creatinine was used as a marker to estimate urine volume. In calculating urine volume, we assumed that creatinine output averaged $28 \mathrm{mg} / \mathrm{kg}$ of BW as estimated by Whittet (2004). Previous investigators have reported similar daily creatinine outputs, ranging from 25 to $30 \mathrm{mg} / \mathrm{kg}$ of BW (McCarthy et al., 1983; Jones et al., 1990). The ratio of the urinary PD allantoin and uric acid to creatinine was used to estimate the relative differences in MCP production (Shingfield and Offer, 1998). Based on estimates of urinary excretion of PD, MCP supply was estimated according to the method of Chen and Gomes (1992).
Table 4. Ingredient composition of the diets fed in experiment 2

\begin{tabular}{|c|c|c|}
\hline \multirow[b]{2}{*}{ Diet ingredient, \% DM } & \multicolumn{2}{|c|}{$\operatorname{Diet}^{1}$} \\
\hline & Control & DDGS $^{2}$ \\
\hline Corn silage & 30.1 & 23.9 \\
\hline Alfalfa hay & 10.9 & 9.4 \\
\hline Alfalfa haylage & 10.9 & 9.3 \\
\hline DDGS & - & 30.1 \\
\hline Ground corn & 16.3 & 12.1 \\
\hline Ground soybean hulls & 10.4 & 10.4 \\
\hline Cottonseed & 6.61 & - \\
\hline SoyPass $^{3}$ & 5.60 & 1.14 \\
\hline Soybean meal & 4.77 & - \\
\hline Ground limestone & 0.73 & 0.98 \\
\hline Tallow & 1.04 & 0.92 \\
\hline Bloodmeal & 0.68 & 0.68 \\
\hline Sodium bicarbonate & 0.52 & 0.52 \\
\hline Magnesium oxide & 0.17 & 0.17 \\
\hline Salt $\mathrm{NaCl}$ & 0.52 & 0.10 \\
\hline Calcium diphosphate & 0.41 & - \\
\hline Urea & 0.26 & - \\
\hline Vitamin ADE premix ${ }^{4}$ & 0.12 & 0.12 \\
\hline Smartamine $\mathrm{M}^{5}$ & 0.04 & 0.04 \\
\hline Trace mineral $^{6}$ & 0.04 & 0.04 \\
\hline Vitamin E premix & 0.03 & 0.03 \\
\hline Sel-Plex $1000^{7}$ & 0.02 & 0.01 \\
\hline
\end{tabular}

${ }^{1}$ Control $=0 \%$ dried distillers grains plus solubles; DDGS $=30 \%$ dried distillers grains plus solubles (DM basis).

${ }^{2} \mathrm{DDGS}=$ dried distillers grains plus solubles.

${ }^{3}$ LignoTech (Overland Park, KS).

${ }^{4}$ Formulated to supply approximately $120,000 \mathrm{IU} / \mathrm{d}$ of vitamin A, $24,000 \mathrm{IU} / \mathrm{d}$ of vitamin $\mathrm{D}$, and $800 \mathrm{IU} / \mathrm{d}$ of vitamin $\mathrm{E}$ in the total ration.

${ }^{5}$ Approximately 75\% CP (Adisseo, Alpharetta, GA).

${ }^{6}$ Formulated to contain $1.0 \% \mathrm{Ca}, 0.50 \% \mathrm{P}, 0.36 \% \mathrm{Mg}$, and $1.3 \% \mathrm{~K}$.

${ }^{7}$ Alltech Inc. (Nicholasville, KY).

\section{Statistical Analyses}

Performance data for experiment 1 were analyzed as a replicated $4 \times 4$ Latin square with model effects for square, period within square, and treatment as fixed effects, as well as cow within square as a random effect by using the MIXED procedure of SAS (version 9.1; SAS Institute, 2004). The linear model for this experiment is written as follows:

$$
y_{i j k(m)}=\mu+\tau_{m}+\beta(\tau)_{i m}+\rho(\tau)_{j m}+\alpha_{K}+\varepsilon_{i j k m},
$$

where $y_{i j k m}$ represents observation $i j k m ; \mu$ represents the overall mean; $\tau_{m}$ represents the fixed effect of square $m ; \beta(\tau)_{\text {im }}$ represents the random effect of cow $i$ within square $m ; \rho(\tau)_{j m}$ represents the fixed effect of period $j$ within square $m$; and $\alpha_{\kappa}$ represents the fixed effect of treatment $\kappa$. The residual terms $\varepsilon_{i j \kappa m}$ are assumed to be normally, independently, and identically distributed, with variance $\sigma_{e}^{2}$. Performance and PD data for experiment 2 were analyzed as a 3 -period 
Table 5. Chemical composition of diets fed in experiment 2

\begin{tabular}{lcc}
\hline & \multicolumn{2}{c}{ Diet $^{1}$} \\
\cline { 2 - 3 } Chemical, \% of DM & Control & DDGS $^{2}$ \\
\hline DM, \% & 53.3 & 52.9 \\
CP & 19.7 & 19.5 \\
RUP, ${ }^{3}$ \% of CP & 35.5 & 41.4 \\
RDP, ${ }^{3} \%$ of CP & 64.5 & 58.6 \\
Starch & 22.4 & 20.6 \\
NDF & 34.6 & 36.2 \\
ADF & 22.9 & 22.8 \\
Lignin & 3.93 & 3.06 \\
NE ${ }^{3}$ Mcal/kg & 1.50 & 1.51 \\
Ether extract & 5.27 & 6.11 \\
NFC & 36.99 & 37.8 \\
Ash & 7.22 & 7.71 \\
Ca & 0.93 & 0.79 \\
Mg & 0.35 & 0.50 \\
P & 0.38 & 0.25 \\
K & 1.46 & 1.28 \\
S & 0.24 & 0.38 \\
\hline
\end{tabular}

${ }^{1}$ Control $=0 \%$ dried distillers grains plus solubles; DDGS $=30 \%$ dried distillers grains plus solubles (DM basis).

${ }^{2} \mathrm{DDGS}=$ dried distillers grains plus solubles.

${ }^{3}$ According to the NRC (2001).

${ }^{4}$ Calculated by the difference $100-(\% \mathrm{NDF}+\% \mathrm{CP}+\%$ Fat $+\%$ Ash $)$.

crossover design with model effects for sequence, period within sequence, and treatment as fixed effects, as well as cow within sequence as a random effect by using the MIXED procedure of SAS (version 9.1; SAS Institute, 2004). The model for this crossover design is that according to Grizzle (1965) except that the residual effect is not included. Specifically, the model for this experiment is written as follows:

$$
y_{i j k l m}=\mu+\pi_{i}+\beta(\pi)_{i j}+\rho_{K}+\gamma_{l}+\lambda_{m}+e_{i j k l m},
$$

where $\mu$ is the general mean; $\Pi_{i}$ represents the fixed effect of sequence $i, \beta(\Pi)_{i j}$ is the random effect of the $j$ th
Table 7. Protein digestibilities for dried distillers grains plus solubles (DDGS) and bloodmeal samples fed during experiment 1 using the mobile bag technique (Kononoff et al., 2007)

\begin{tabular}{lcc}
\hline Item & DDGS & Bloodmeal \\
\hline RUP, \% of CP & 55.1 & 84.0 \\
dRUP, ${ }^{1} \%$ of RUP & 91.0 & 76.2 \\
TT CP digestibility, ${ }^{2} \%$ of CP & 95.0 & 81.0 \\
\hline
\end{tabular}

${ }^{1} \mathrm{dRUP}=$ digestibility of RUP.

${ }^{2} \mathrm{TT} \mathrm{CP}$ digestibility = total-tract $\mathrm{CP}$ digestibility.

cow within the $i$ th sequence, $\rho_{\kappa}$ is the effect of the $k$ th period, $\gamma_{l}$ is the fixed effect of the effect of the $l$ th diet, $\lambda_{m}$ is the fixed effect of the $m$ th parity, and $e_{i j k m}$ reflects the random error in the measurement of the response. Significance for all models was declared at $P \leq 0.05$, and trends were discussed at $P \leq 0.15$. The PDIFF option was used to test treatment differences among least squares means, and all means presented are least squares means. Period $\times$ treatment interactions were tested for the primary response variable, $3.5 \% \mathrm{FCM}$, and were not significant and consequently were pooled with the residual.

\section{RESULTS AND DISCUSSION}

\section{Feed and Ration Chemical Composition and Particle Size}

Ingredients and chemical composition of experimental diets are listed in Table 1 and 2 for experiment 1 and Tables 4 and 5 for experiment 2 . Diets were formulated to be similar in $\mathrm{CP}, \mathrm{NDF}$, and energy. The chemical composition of the control and treatment diets used in experiments 1 and 2 were slightly different because of differences in forage and DDGS composition. The control and $30 \%$ DDGS diet for experiment 1 had average CP,

Table 6. Chemical composition of dried distillers grains plus solubles (DDGS) and forage sources fed during experiment 1 (DM basis)

\begin{tabular}{|c|c|c|c|c|c|c|c|c|}
\hline \multirow[b]{2}{*}{ Item } & \multicolumn{2}{|c|}{ DDGS } & \multicolumn{2}{|c|}{ Corn silage } & \multicolumn{2}{|c|}{ Haylage } & \multicolumn{2}{|c|}{ Alfalfa hay } \\
\hline & Mean & $\mathrm{SD}$ & Mean & $\mathrm{SD}$ & Mean & $\mathrm{SD}$ & Mean & $\mathrm{SD}$ \\
\hline DM, \% & 88.5 & 0.62 & 36.6 & 2.36 & 26.9 & 1.20 & 91.0 & 0.41 \\
\hline $\mathrm{CP}, \%$ & 29.3 & 1.88 & 8.35 & 1.49 & 23.8 & 1.09 & 22.2 & 0.49 \\
\hline Soluble CP, \% of CP & 18.3 & 8.42 & 60.5 & 7.41 & 69.0 & 3.24 & 40.0 & 1.00 \\
\hline NDF, $\%$ & 37.3 & 0.69 & 39.3 & 1.05 & 44.2 & 3.17 & 39.0 & 3.52 \\
\hline $\mathrm{ADF}, \%$ & 18.5 & 2.84 & 22.2 & 1.84 & 36.2 & 5.02 & 31.1 & 2.21 \\
\hline Starch, \% & 8.25 & 0.64 & 36.3 & 1.92 & - & - & - & - \\
\hline Ether extract, \% & 9.55 & 0.64 & 3.00 & - & 3.8 & - & 1.7 & - \\
\hline $\mathrm{NFC},{ }^{1} \%$ & 25.4 & 1.67 & 43.8 & 2.42 & 24.0 & 2.12 & 31.1 & 3.59 \\
\hline $\mathrm{Ca}, \%$ & 0.26 & 0.06 & 0.29 & 0.05 & 1.40 & 0.05 & 1.50 & 0.05 \\
\hline $\mathrm{Mg}, \%$ & 0.71 & 0.14 & 0.26 & 0.01 & 0.36 & 0.03 & 0.30 & 0.02 \\
\hline $\mathrm{P}, \%$ & 0.29 & 0.03 & 0.15 & 0.01 & 0.22 & 0.01 & 0.28 & 0.01 \\
\hline $\mathrm{K}, \%$ & 1.08 & 0.06 & 0.99 & 0.06 & 3.50 & 0.14 & 2.51 & 0.06 \\
\hline
\end{tabular}

${ }^{1}$ Calculated by difference $100-(\% \mathrm{NDF}+\% \mathrm{CP}+\%$ Fat $+\%$ Ash $)$. 
Table 8. Chemical composition of dried distillers grains plus solubles (DDGS) and forage sources fed during experiment 2 (DM basis)

\begin{tabular}{|c|c|c|c|c|c|c|c|c|}
\hline $\begin{array}{l}\text { Chemical composition, } \\
\% \text { of DM }\end{array}$ & \multicolumn{2}{|c|}{ DDGS } & \multicolumn{2}{|c|}{ Corn silage } & \multicolumn{2}{|c|}{ Haylage } & \multicolumn{2}{|c|}{ Alfalfa hay } \\
\hline DM & 88.5 & 0.50 & 38.8 & 1.40 & 48.0 & 17.8 & 90.7 & 0.96 \\
\hline Soluble CP, $\%$ of CP & 14.3 & 0.58 & 60.7 & 0.58 & 59.3 & 9.45 & 37.7 & 0.58 \\
\hline NDF & 34.3 & 0.47 & 39.2 & 5.92 & 44.0 & 1.05 & 38.8 & 2.55 \\
\hline $\mathrm{ADF}$ & 19.5 & 1.21 & 21.9 & 2.36 & 36.0 & 0.74 & 30.0 & 1.65 \\
\hline $\mathrm{Ca}$ & 0.11 & 0.02 & 0.32 & 0.03 & 1.56 & 0.18 & 1.34 & 0.24 \\
\hline $\mathrm{Mg}$ & 0.85 & 0.06 & 0.23 & 0.02 & 0.28 & 0.05 & 0.23 & 0.02 \\
\hline $\mathrm{P}$ & 0.34 & 0.02 & 0.14 & 0.01 & 0.28 & 0.03 & 0.33 & 0.02 \\
\hline $\mathrm{K}$ & 1.08 & 0.17 & 0.84 & 0.06 & 3.08 & 0.47 & 2.95 & 0.23 \\
\hline
\end{tabular}

${ }^{1}$ Calculated by difference $100-(\% \mathrm{NDF}+\% \mathrm{CP}+\% \mathrm{Fat}+\% \mathrm{Ash})$.

NDF, and energy contents of 19.4 and $18.1 \% \mathrm{CP}, 34.6$ and $37.1 \% \mathrm{NDF}$, and 1.50 and $1.51 \mathrm{Mcal} / \mathrm{kg}$ of $\mathrm{NE}_{\mathrm{L}}$, respectively. The control and DDGS diets for experiment 2 had averages of 19.7 and $19.5 \% \mathrm{CP}, 34.6$ and $36.2 \%$ $\mathrm{NDF}$, and 1.50 and $1.51 \mathrm{Mcal} / \mathrm{kg}$ of $\mathrm{NE}_{\mathrm{L}}$, respectively. Tallow was added to both diets to maintain similar $\mathrm{NE}_{\mathrm{L}}$ values. Because of the addition of tallow and the relatively high concentration of fat in the DDGS, the control diets had a slightly lower EE content, $5.14 \%$ for experiment 1 and $5.27 \%$ for experiment 2 , compared with the DDGS diets, which had $5.68 \% \mathrm{EE}$ in experiment 1 and $6.11 \% \mathrm{EE}$ in experiment 2. The $\mathrm{P}$ content of DDGS listed by the NRC (2001) is $0.72 \%$ DM. This is greater than the DDGS fed in experiment $1(0.29 \%)$ and experiment $2(0.34 \%)$, because the DDGS used in the current experiment were produced from a dry-milling process that partially removes the germ, which is high in $\mathrm{P}$ (Ponnampalam et al., 2004). Because of this process, we expected the feed to be lower in fat and P. On completion of the experiment, the reduction in fat was less than expected and the reduction in $\mathrm{P}$ was greater than expected. As a result, the formulated rations resulted in $\mathrm{P}$ concentrations $(0.36 \%)$ below those recommended by the NRC (2001). Although this P concentration is low, we speculate that this would have minimal effects on lactational performance, because lower $\mathrm{P}$ diets were fed only for short periods. When cows consume these diets, it is likely that sufficient body stores of $\mathrm{P}$ would likely be mobilized to meet requirements. In addition, the NRC (2001) publication notes that P deficiency is most commonly observed when animals consume low-P forages at concentrations less than $0.25 \%$.

The ration particle size for experiment 1 is listed in Table 3. The DDGS diet had a finer particle size compared with the control diet, which was expected given the partial replacement of a portion of the forage sources with DDGS. The diet containing DDGS con- tained approximately $21.7 \%$ material with a particle size of less than $1.18 \mathrm{~mm}$, compared with $16.9 \%$ for the control diet (as-fed basis). The recommendation for particle size based on TMR consisting of very low to no inclusion of by-products is 2 to $8 \%$ of the ration on the upper sieve (particles $>19 \mathrm{~mm}$ ), 30 to $50 \%$ in the middle sieve (particles 8 to $19 \mathrm{~mm}$ ), 30 to $50 \%$ in the lower sieve (particles 1.18 to $8 \mathrm{~mm}$ ), and less than $20 \%$ on the bottom pan (particles $<1.18 \mathrm{~mm}$ ) according to Heinrichs and Kononoff (2002). The control diet followed these guidelines; however, the DDGS diet had a lower proportion that was retained on the $8-\mathrm{mm}$ sieve and a higher proportion of particles $<1.18 \mathrm{~mm}$ than recommended (26.6 and $21.7 \%$ in the $8-\mathrm{mm}$ sieve and $<1.18 \mathrm{~mm}$, respectively). A fine particle size has been reported to decrease the time spent chewing and may increase the incidence of rumen acidosis because of a decrease in rumen $\mathrm{pH}$ (Heinrichs and Kononoff, 2002). Cows consuming a sufficient amount of NDF with a smaller particle size may express the same metabolic disorders as cows consuming a diet deficient in fiber (Heinrichs and Kononoff, 2002). The proportion of forage NDF in all diets fell within the minimum NDF recommendations from the NRC of 15 to $19 \%$ forage NDF. The control diet contained 20.8\% NDF from forage, whereas the DDGS diet contained $17.1 \% \mathrm{NDF}$ from forage.

Table 6 lists the chemical composition of the forages and DDGS fed during experiment 1. The NRC (2001) lists the $\mathrm{CP}$ and $\mathrm{EE}$ concentrations as 29.7 and 10\%, respectively. The CP content of the DDGS used in experiment 1 was similar (29.3\%) and EE was slightly lower (9.95\%). The EE content fell within the range (8.2 to $11.7 \%$ ) reported by Spiehs et al. (2002). Table 8 lists the chemical composition of the forages and DDGS fed during experiment 2 . The DDGS were slightly higher in CP (33.3\%) and EE (10.6\%). Estimates of RUP, dRUP, 
Table 9. The effect of increasing the inclusion of dried distillers grains plus solubles (DDGS) on DMI, milk yield, and milk composition in experiment 1

\begin{tabular}{|c|c|c|c|c|c|c|c|}
\hline \multirow[b]{2}{*}{ Item } & \multicolumn{4}{|c|}{ Treatment } & \multirow[b]{2}{*}{ SEM } & \multicolumn{2}{|c|}{$P$-value } \\
\hline & Control & $10 \%$ DDGS & $20 \%$ DDGS & $30 \%$ DDGS & & Linear & Quadratic \\
\hline $3.5 \% \mathrm{FCM},{ }^{1} \mathrm{~kg} / \mathrm{d}$ & 28.0 & 29.1 & 30.4 & 31.2 & 1.48 & 0.01 & 0.84 \\
\hline Fat, \% & 3.70 & 3.64 & 3.73 & 3.55 & 0.15 & 0.31 & 0.42 \\
\hline Fat yield, kg/d & 1.00 & 1.03 & 1.09 & 1.10 & 0.06 & 0.02 & 0.68 \\
\hline MUN, mg/dL & 15.6 & 15.2 & 14.7 & 14.7 & 0.42 & $<0.01$ & 0.40 \\
\hline $\mathrm{BW}, \mathrm{kg}$ & 650.7 & 650.5 & 656.3 & 658.8 & 15.0 & 0.05 & 0.68 \\
\hline $\mathrm{BCS}^{2}$ & 3.41 & 3.38 & 3.39 & 3.38 & 0.04 & 0.48 & 0.66 \\
\hline $\mathrm{FC}^{3}$ & 1.30 & 1.29 & 1.34 & 1.29 & 0.06 & 0.92 & 0.69 \\
\hline
\end{tabular}

${ }^{1} 3.5 \% \mathrm{FCM}=0.432 \times$ milk $(\mathrm{kg} / \mathrm{d})+16.23 \times$ fat $(\mathrm{kg} / \mathrm{d})($ Tyrrell and Reid, 1965) .

${ }^{2}$ Scale of 1 to 5 .

${ }^{3}$ Feed conversion $=3.5 \%$ FCM/DMI.

and TT CP digestibility for DDGS and bloodmeal fed in experiment 1 are listed in Table 7. Based on estimates using the in situ technique, the observed RUP content for DDGS used in the current experiment was 55.1\%. Although this method assumes that all protein disappearing from the bag is completely degraded (Norberg et al., 2007), it should be noted that a small proportion of protein may wash out of the bag and may not be degraded in the rumen, and this may result in an overestimate of rumen protein degradability. In the current experiment, dRUP was observed to be $91 \%$ and is higher that the estimate listed in the Dairy NRC (2001) publication (80\%) and that observed by Masoero et al. (1994; 86.1\%) but is similar to that reported by Kononoff et al. (2007; 88.7\%). The levels of RUP and dRUP of protein contained in SoyPass have been evaluated previously by using the mobile bag technique (Kononoff et al., 2007). In this study, we observed that the RUP and dRUP of SoyPass were $75.7 \%$ CP and $96.6 \%$ RUP. Although the bypass protein value of DDGS is not as high as that of SoyPass, these observations indicate that the RUP component of DDGS is highly digestible and potentially greater than that assumed by the NRC (2001) model.

\section{Feed Intake}

In experiment 1, DMI (Table 9) increased linearly $(P<0.01)$ with increasing inclusion of DDGS in the diet compared with the control diet $(21.4,22.4,23.0$, and $24.0 \mathrm{~kg} / \mathrm{d}$ for the $0,10,20$, and 30\% DDGS diet, respectively). Similarly, in experiment 2 inclusion of DDGS resulted in a significant increasing effect $(P<$ 0.01) on DMI for the control diet $(22.8 \mathrm{~kg} / \mathrm{d})$ compared with the $30 \%$ DDGS diet $(24.1 \mathrm{~kg} / \mathrm{d})$. The linear in- crease in DMI may be due to the smaller particle size and increased passage rate with the DDGS compared with the control diet (Allen, 2000). Feeding DDGS has resulted in differing responses on DMI (Grings et al., 1992). Grings et al. (1992) evaluated the effect on milk yield and milk composition of CP concentration in diets using increasing concentrations of DDGS. In that experiment, DDGS replaced a portion of the ground corn and was included at $32 \%$ of the ration DM, but no effect on DMI was observed. Although the proportions of DDGS included in treatment diets were similar to those of the current experiment, they differed, because in the current experiment, DDGS also replaced a portion of the forages. Thus, the effects of including DDGS on DMI are likely also a function of the type of feed replaced, and the effects observed may have been due to a difference in ration particle size, which has been observed to be inversely related to DMI (Kononoff and Heinrichs, 2003).

\section{Milk Production and Composition}

Milk production and milk components for experiment 1 are listed in Table 9. There was no effect of treatment on the percentage of milk fat, which averaged $3.66 \pm$ $0.15 \%$ across treatments. Total milk yield increased linearly $(P=0.02)$ with increasing concentrations of DDGS in the diet $(27.4,28.5,29.3$, and $30.6 \mathrm{~kg} / \mathrm{d}$ for the control and 10, 20, and 30\% DDGS). Similar milk responses have been noted in research by Anderson et al. (2006), Clark and Armentano (1997), and Grings et al. (1992). The increase in milk yield can be attributed to the increase in DMI and improved energy status. Similarly, $3.5 \%$ FCM yield increased linearly $(P=0.01)$ with the increase in DDGS, ranging from $28.0 \mathrm{~kg} / \mathrm{d}$ for 
Table 10. The effect of increasing dried distillers grains plus solubles (DDGS) in the diet of lactating Holstein cows on milk fatty acid composition in experiment 1

\begin{tabular}{|c|c|c|c|c|c|c|c|}
\hline 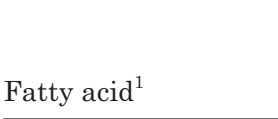 & \multicolumn{4}{|c|}{ Treatment } & $\mathrm{SEM}^{2}$ & \multicolumn{2}{|c|}{$P$-value } \\
\hline $\mathrm{C} 12: 0$ & 2.21 & 2.16 & 2.29 & 2.38 & 0.14 & 0.16 & 0.48 \\
\hline C14:0 & 9.04 & 9.08 & 8.39 & 8.53 & 0.34 & 0.10 & 0.87 \\
\hline C16:0 & 29.5 & 28.8 & 31.4 & 25.1 & 3.09 & 0.42 & 0.35 \\
\hline C16:1 & 1.66 & 1.51 & 1.26 & 1.43 & 0.25 & 0.68 & 0.72 \\
\hline C18:1 cis-9 & 24.0 & 24.6 & 24.6 & 24.8 & 0.66 & 0.33 & 0.64 \\
\hline CLA $^{3}$ cis -9, trans -11 & 0.34 & 0.55 & 0.80 & 0.98 & 0.06 & $<0.01$ & 0.79 \\
\hline C18:2 & 2.96 & 3.82 & 4.78 & 5.59 & 0.21 & $<0.01$ & 0.88 \\
\hline Other ${ }^{4}$ & 5.04 & 4.64 & 3.76 & 5.70 & 1.19 & 0.83 & 0.31 \\
\hline Unidentified $^{5}$ & 5.09 & 4.98 & 4.87 & 5.77 & 0.57 & 0.43 & 0.36 \\
\hline
\end{tabular}

${ }^{1}$ Expressed as number of carbons:number of double bonds.

${ }^{2}$ Highest standard error of treatment is shown.

${ }^{3} \mathrm{CLA}=$ conjugated linoleic acid.

${ }^{4}$ Sum of C4:0, C6:0, C8:0, C14:1, and C15:0.

${ }^{5}$ Unidentified peaks.

the control diet up to $31.2 \mathrm{~kg} / \mathrm{d}$ for the $30 \%$ DDGS diet. Milk protein yield increased significantly $(P=0.03)$ with increasing concentrations of DDGS (0.86, 0.91, 0.92 , and $0.95 \mathrm{~kg} / \mathrm{d}$, respectively), as did milk fat yield $(P=0.02)$, which increased from $1.0 \mathrm{~kg} / \mathrm{d}$ for the control diet to $1.10 \mathrm{~kg} / \mathrm{d}$ for the $30 \%$ DDGS diet. Increases in milk protein yields were also reported by Anderson et al. (2006) when feeding a control diet and 10 and 20\% DDGS, which resulted in an increase in protein yield from $1.20 \mathrm{~kg} / \mathrm{d}$ for the control diet to $1.29 \mathrm{~kg} / \mathrm{d}$ for the $20 \%$ DDGS diet. The increase in milk protein yield in this study may be due to more energy being available for milk protein synthesis and to an increase in milk yield. Concentration of MUN significantly $(P<0.01)$ decreased with increasing concentrations of DDGS (15.6, 15.2, 14.7, and $14.7 \mathrm{mg} / \mathrm{dL}$, respectively). This decrease may be due to the increase in milk production diluting the urea in the milk or to a decrease in RDP when rations contained DDGS. The profiles of milk fatty acids across treatments are listed in Table 10. The concentrations of C12:0, C14:0, C16:0, C16:1, C18:0, and C18:1 were not observed to be affected. Notably, the concentrations of $\mathrm{C} 18: 1$ trans-9, conjugated linoleic acid cis-9, trans-11, and C18:2 were observed to increase linearly with the increase of DDGS in the diet from 0 to $30 \%$ (dietary DM), likely because of an increase in long-chain fatty acids in these diets, as observed by Anderson et al. (2006).

Milk production results for experiment 2 are listed in Table 11. Similar to experiment 1, intake increased from 22.8 to $24.1 \mathrm{~kg} / \mathrm{d}$ as the amount of DDGS increased from 0 to $30 \%$ of dietary DM. However, in contrast to experiment 1 , there were no significant differences for milk yield, $3.5 \% \mathrm{FCM}$, fat or protein yield or percentage, and feed conversion in experiment 2 . There was a significant $(P<0.01)$ increase in the concentration of MUN with the inclusion of DDGS $(14.0 \mathrm{mg} / \mathrm{dL}$ for the control diet compared with $14.9 \mathrm{mg} / \mathrm{dL}$ for the DDGS diet).

\section{$P D$ and Creatinine Excretion}

Estimation of urinary PD excretion is an indirect, noninvasive method of estimating treatment differences in rumen MCP production (Moorby et al., 2006). Table 12 lists the effects of feeding DDGS compared with a control diet on urinary creatinine, $\mathrm{PD}$, the ratio of $\mathrm{PD}$ to creatinine, the ratio of allantoin to creatinine, and estimated MCP production as estimated by PD production in experiment 2 (Chen and Gomes, 1992). We were unable to detect measurable concentrations of xanthine in any samples. We hypothesized that partial replacement of corn grain with DDGS could increase rumen $\mathrm{pH}$ and result in an increase in total ruminal MCP production. This may explain, in part, the observed increase in milk yield and milk components in experiment 1. However, total PD production was not different $(P=0.23)$, averaging $394.2 \mathrm{mmol} / \mathrm{d}$. Similarly, estimated MCP production was not significantly different $(P=0.23)$, averaging $1,597.9 \mathrm{~g} / \mathrm{d}$ for the control diet and $1,688.8 \mathrm{~g} / \mathrm{d}$ for the DDGS diet. Moorby et al. (2006) stated that there is a positive correlation between total DMI and total urinary PD excretion, as well as microbial $\mathrm{N}$ flow to the duodenum. In that study, they evaluated 
Table 11. The effect of feeding dried distillers grains plus solubles (DDGS) grains, compared with the control diet, on feed intake, milk yield, and milk composition in experiment 2

\begin{tabular}{|c|c|c|c|c|}
\hline \multirow[b]{2}{*}{ Item } & \multicolumn{2}{|c|}{ Treatment $^{1}$} & \multirow[b]{2}{*}{$\mathrm{SEM}^{2}$} & \multirow[b]{2}{*}{$P$-value } \\
\hline & Control & DDGS & & \\
\hline DMI, kg/d & 22.8 & 24.1 & 0.74 & $<0.01$ \\
\hline Milk yield, kg/d & 33.2 & 34.2 & 1.41 & 0.30 \\
\hline $3.5 \% \mathrm{FCM}^{3}{ }^{3} \mathrm{~kg} / \mathrm{d}$ & 34.1 & 34.9 & 1.46 & 0.33 \\
\hline Fat, \% & 3.67 & 3.65 & 0.08 & 0.79 \\
\hline Fat yield, kg/d & 1.22 & 1.24 & 0.06 & 0.41 \\
\hline Protein, \% & 2.98 & 2.99 & 0.04 & 0.85 \\
\hline Protein yield, kg/d & 0.98 & 1.02 & 0.04 & 0.18 \\
\hline MUN, mg/dL & 14.0 & 14.9 & 0.31 & $<0.01$ \\
\hline $\mathrm{BW}, \mathrm{kg}$ & 644.8 & 649.8 & 9.44 & 0.10 \\
\hline $\mathrm{BCS}^{4}$ & 3.15 & 3.13 & 0.05 & 0.64 \\
\hline $\mathrm{FC}^{5}$ & 1.52 & 1.47 & 0.06 & 0.22 \\
\hline
\end{tabular}

${ }^{1}$ Control $=0 \%$ DDGS; DDGS $=30 \%$ DDGS (DM basis).

${ }^{2}$ Highest standard error of treatment is shown.

${ }^{3} 3.5 \% \mathrm{FCM}=0.432 \times$ milk $(\mathrm{kg} / \mathrm{d})+16.23 \times$ fat $(\mathrm{kg} / \mathrm{d})($ Tyrrell and Reid, 1965)

${ }^{4}$ Scale of 1 to 5 .

${ }^{5}$ Feed conversion $=3.5 \% \mathrm{FCM} / \mathrm{DMI}$.

the effect of changing the forage-to-concentrate ratios on the relationship between urinary PD and duodenal microbial protein flow. The investigators observed an increase in total DMI, resulting in a subsequent increase in total PD excretion. These results are different from those of the current study, in which differences in PD production were not observed along with differences in DMI. Although a difference in the concentration of hypoxanthine in the urine was observed, the rationale for differences was not apparent.

\section{CONCLUSIONS}

Dairy diets may be formulated to contain as much as 30\% DDGS of dietary DM and may result in an increase in DMI, milk yield, and 3.5\% FCM. Addition of DDGS may also increase protein and fat yields in milk. No maximum rate of inclusion was identified in experiment 1 for feeding DDGS to lactating dairy cows. The increase in milk production can be attributed to the increase in DMI and not to an increase in MCP produc-

Table 12. The effect of feeding dried distillers grains plus solubles (DDGS) on daily excretion of urinary creatinine, allantoin, uric acid, and estimated rumen microbial CP production

\begin{tabular}{|c|c|c|c|c|}
\hline \multirow[b]{2}{*}{ Item } & \multicolumn{2}{|c|}{ Treatment $^{1}$} & \multirow[b]{2}{*}{$\mathrm{SEM}^{2}$} & \multirow[b]{2}{*}{$P$-value } \\
\hline & Control & DDGS & & \\
\hline Creatinine, $\mathrm{m} M$ & 5.69 & 6.12 & 0.25 & 0.23 \\
\hline Allantoin, $\mathrm{m} M$ & 11.9 & 13.3 & 0.45 & 0.04 \\
\hline Uric Acid, $\mathrm{m} M$ & 1.10 & 1.06 & 0.09 & 0.73 \\
\hline Hypoxanthine, $\mathrm{m} M$ & 2.05 & 5.26 & 0.37 & $<0.01$ \\
\hline $\mathrm{PD},{ }^{3} \mathrm{~m} M$ & 13.0 & 14.3 & 0.50 & 0.07 \\
\hline PD:creatinine & 2.39 & 2.49 & 0.08 & 0.29 \\
\hline Allantoin:creatinine & 2.19 & 2.31 & 0.07 & 0.19 \\
\hline Creatinine production, ${ }^{4} \mathrm{mmol} / \mathrm{d}$ & 160.9 & 162.2 & 2.33 & 0.10 \\
\hline $\mathrm{PD}$ production, ${ }^{5} \mathrm{mmol} / \mathrm{d}$ & 384.5 & 403.8 & 12.7 & 0.23 \\
\hline Allantoin production, ${ }^{6} \mathrm{mmol} / \mathrm{d}$ & 352.3 & 374.4 & 12.0 & 0.14 \\
\hline Microbial $\mathrm{CP},{ }^{7} \mathrm{~g} / \mathrm{d}$ & $1,597.9$ & $1,688.8$ & 60.1 & 0.23 \\
\hline \multicolumn{5}{|c|}{${ }^{1}$ Control $=0 \%$ DDGS $;$ DDGS $=30 \%$ DDGS (DM basis). } \\
\hline \multicolumn{5}{|c|}{${ }^{2}$ Highest standard error of treatment means is shown. } \\
\hline \multicolumn{5}{|c|}{${ }^{3} \mathrm{PD}=$ total purine derivatives (allantoin + uric acid) } \\
\hline \multicolumn{5}{|c|}{${ }^{4}$ Creatinine production $=(28 \times \mathrm{BW}) / 113.1$} \\
\hline \multicolumn{5}{|c|}{${ }^{5} \mathrm{PD}$ production $=[$ creatinine production $\times(\mathrm{PD}:$ creatinine $)]$} \\
\hline \multicolumn{5}{|c|}{${ }^{6}$ Allantoin production $=$ [creatinine production $\times($ allantoin:creatinine $\left.)\right]$} \\
\hline${ }^{7}$ Microbial CP $(\mathrm{g} / \mathrm{d})=(\{[\mathrm{PD}$ prod & $\left.\left.\mathrm{W}^{0.075}\right)\right] / 0.8$ & $70 \times 6.25$ & 089 & \\
\hline
\end{tabular}


tion. The DDGS is a highly digestible fiber source that may be used by the dairy industry while maintaining milk production and milk components, and in some cases may improve milk production.

\section{ACKNOWLEDGMENTS}

This research was a component of a USDA, NC Regional Project NC-1119. The authors thank the personnel at the University of Nebraska Dairy Research Unit (Mead, NE) for care of the experimental animals during the experiment. The editorial suggestions of J. Miner are also greatly appreciated.

\section{REFERENCES}

Allen, M. S. 2000. Effects of diet on short-term regulation of feed intake by lactating dairy cattle. J. Dairy Sci. 83:1598-1624.

Anderson, J. L., D. J. Schingoethe, K. F. Kalscheur, and A. R. Hippen. 2006. Evaluation of dried and wet distillers grains included at two concentrations in the diets of lactating dairy cows. J. Dairy Sci. 89:3133-3142.

AOAC. 2000. Official Methods of Analysis. Vol. 1 and 2. 17th ed. AOAC Int., Gaithersburg, MD.

Chen, X. B., and M. J. Gomes. 1992. Estimation of microbial protein supply to sheep and cattle based on urinary excretion of purine derivatives-An overview of the technical details. Int. Feed. Res. Unit, Occas. Publ. Rowett Res. Inst., Bucksburn, Aberdeen, UK.

Clark, P. W., and L. E. Armentano. 1997. Replacement of alfalfa neutral detergent fiber with a combination of nonforage fiber sources. J. Dairy Sci. 80:675-680.

Getachew, G., P. H. Robinson, E. J. DePeters, and S. J. Taylor. 2004. Relationship between chemical composition, dry matter degradation and in vitro gas production of several ruminant feeds. Anim. Feed Sci. Technol. 11:57-71.

Gonda, H. L. 1995. Nutritional status of ruminants determined from excretion and concentration of metabolites in body fluids. $\mathrm{PhD}$ Diss. Swedish Univ. Agric. Sci. Dept. Anim. Nutr. Management, Uppsala, Sweden.

Grings, E. E., R. E. Roffler, and D. P. Deitelhoff. 1992. Responses of dairy cows to additions of distillers dried grains with solubles in alfalfa-based diets. J. Dairy Sci. 75:1946-1953.

Grizzle, H. 1965. The use of non-parametric methods in the statistical analysis of the two period change-over design. Biometrics 1972:577-578.

Ham, G. A., R. A. Stock, T. J. Klopfenstein, E. M. Larson, D. H. Shain, and R. P. Huffman. 1994. Wet corn distillers byproducts compared with dried corn distillers grains with solubles as a source of protein and energy for ruminants. J. Anim. Sci. $72: 3246-3257$.

Heinrichs, A. J. and P. J. Kononoff. 2002. Evaluating particle size of forages and TMRs using the new Penn State forage particle separator. Tech. Bull. DAS 96-20. Pennsylvania State Univ., College Agric. Sci., Cooperative Ext., University Park, PA.

Jones, S. J., D. L. Starkey, C. R. Calkins, and J. D. Crouse. 1990. Myofibrillar protein turnover in feed-restricted and realimented beef cattle. J. Anim. Sci. 68:2707-2715.

Kononoff, P. J., and A. J. Heinrichs. 2003. The effect of decreasing alfalfa haylage particle size on dairy cows in early lactation. J. Dairy Sci. 86:1445-1457.

Kononoff, P. J., S. K. Ivan, and T. J. Klopfenstein. 2007. Estimation of the proportion of feed digested in the small intestine of cattle consuming wet corn gluten feed. J. Dairy Sci. 90:2377-2385.
Kramer, J. K., V. Fellner, M. E. Dugan, F. D. Sauer, M. M. Mossoba, and M. P. Yurawecz. 1997. Evaluating acid and base catalysts in the methylation of milk and rumen fatty acid with special emphasis on conjugated dienes and total trans fatty acids. Lipids $32: 1219-1228$.

Leonardi, C., M. Stevenson, and L. E. Armentano. 2003. Effect of two levels of crude protein and methionine supplementation on performance of dairy cows. J. Dairy Sci. 86:4033-4042.

Masoero, F., L. Fiorentini, F. Rossi, and A. Piva. 1994. Determination of nitrogen intestinal digestibility in ruminants. Anim. Feed Sci. Technol. 48:253-263.

McCarthy, F. D., W. G. Bergen, and D. R. Hawkins. 1983. Muscle protein turnover in cattle of differing genetic backgrounds as measured by urinary $\mathrm{N}^{r}$-methylhistidine excretion. J. Nutr. 113:2455-2463.

Moorby, J. M., R. J. Dewhurst, R. T. Evans, and J. L. Danelon. 2006. Effects of dairy cow diet forage proportion on duodenal nutrient supply and urinary purine derivative excretion. J. Dairy Sci. 89:3552-3562.

NRC. 2001. Nutrient Requirements of Dairy Cattle. 7th rev. ed. Natl. Acad. Sci., Washington, DC.

Norberg, E., H. Volden, and O. M. Harstad. 2007. Technical note: Assessment of recovery site of mobile nylon bags for measuring ileal digestibility of starch in dairy cows. J. Dairy Sci. 90:418421.

Pantoja, J., J. L. Firkins, M. L. Eastridge, and B. L. Hull. 1994. Effects of fat saturation and source of fiber on site of nutrient digestion and milk production by lactating dairy cows. J. Dairy Sci. 77:2341-2356.

Ponnampalam, E., D. B. Steele, D. Burgdorf, and D. McCalla. 2004. Effect of germ and fiber removal on production of ethanol from corn. Appl. Biochem. Biotechnol. 115:837-842.

SAS Institute. 2004. SAS/Stat 9.1 User's Guide. Vol. 4. SAS Inst. Inc., Cary, NC.

Shingfield, K. J., and N. W. Offer. 1998. Evaluation of the spot urine sampling technique to assess urinary purine derivative excretion in lactating dairy cows. J. Anim. Sci. 66:557-568.

Shingfield, K. J., and N. W. Offer. 1999. Simultaneous determination of purine metabolites, creatinine, and pseudouridine in ruminant urine by reversed-phase high-performance liquid chromatography. J. Chromatogr. B Analyt. Technol. Biomed. Life Sci. 723:81-94.

Spiehs, M. J., M. H. Whitney, and G. C. Shurson. 2002. Nutrient database for distiller's dried grains with solubles produced from new ethanol plants in Minnesota and South Dakota. J. Anim. Sci. 80:2639-2645.

Tyrrell, H. F., and J. T. Reid. 1965. Prediction of the energy value of cow's milk. J. Dairy Sci. 48:1215-1223.

Valadares, R. F. D., G. A. Broderick, S. C. Valadares Filho, and M. K. Clayton. 1999. Effect of replacing alfalfa silage with high moisture corn on ruminal protein synthesis estimated from excretion of total purine derivatives. J. Dairy Sci. 82:2686-2696.

Van Soest, P. J. 1994. Nutritional Ecology of the Ruminant. 2nd ed. Pages 292-296. Cornell University Press, Ithaca, NY.

Vanzant, E. S., R. C. Cochran, and E. C. Titgemeyer. 1998. Standardization of in situ techniques for ruminant feedstuff evaluation. J. Anim. Sci. 76:2717-2729.

Voelker Linton, J. A., and M. S. Allen. 2007. Nutrient demand affects ruminal digestion responses to a change in dietary forage concentration. J. Dairy Sci. 90:4770-4779.

Whittet, K. M. 2004. Factors affecting variability in urinary creatinine and purine derivative excretion in beef cattle. MS Diss. Univ. Nebraska-Lincoln.

Wildman, E. E., G. M. Jones, P. E. Wagner, H. F. Troutt, and T. N. Lesch. 1982. A dairy cow body condition scoring system and its relationship to selected production characteristics. J. Dairy Sci. 65:495-501. 